\title{
Antioxidant effects of ethanol extracts from plants on semi-dried eels
}

\author{
Hee-Sun Song* \\ Department of Food and Nutrition, Gwangju Health University, Gwangju 62287, Korea
}

반건조 장어에 대한 식물 주정 추출물의 항산화 효과

\author{
송희순* \\ 광주보건대학교 식품영양과
}

\begin{abstract}
Ethanol extracts from Ginger, cinnamon, dried onions, and Hutgae (Hovenia dulcis Thunb.) trunk were pre-treated on the eels to find out their peroxidation preventing properties on the eels. The eels were evenly coated with the extract equivalent to $2 \%$ of their total weight and dried for $15 \mathrm{~h}$ at $35^{\circ} \mathrm{C}$ using an air blower. Antioxidative properties of ethanol extracts were reviewed through the DPPH scavenging effect, and the acid value, peroxide value, and linoleic acid value of the semi-dried eels, and also the delayed reaction of peroxidation of semi-dried eel oil. The highest level of DPPH scavenging was cinnamon extract, followed by Hutgae trunk extract, dried onions, and ginger $(\mathbf{p}<\mathbf{0 . 0 5})$. Regarding acid value of eels refrigerated for 21 days, ginger extract recorded the lowest. As in the preventative effect of free fatty acid, ginger extract prevented the early hydroperoxide during the drying process of eels. During the 20 days of peroxide-induced-reaction period, the most effective preventer of linoleic acid peroxide was Hutgae trunk extract and ginger and dried onion extracts were followed. During the 20 days of peroxide-induced-reaction period, the effective peroxidation preventers of semi-dried eel oil were ginger, cinnamon, and dried onions extracts. Hutgae trunk extract was found to delay effectively the peroxidation induction period of eel oil. In conclusion, pre-application of ethanol extracts from ginger and cinnamon was effective in delaying peroxidation of eels in the drying process and of semi-dried eels in refrigeration, and extracts from dried onions and Hutgae trunk were stalling the induced peroxidation and restricting peroxide content to some degrees.
\end{abstract}

Key words : eel, peroxide, antioxidant, ginger, cinnamon

\section{서 론}

식품의 산화는 주로 지질 성분이 산소와 결합하면서 촉 진되며, 가수분해, 고온가열에 의한 자동산화 등에 의해 유지 및 식품이 산패되어 식품의 품질에 영향을 미치게 된다(1). 한국인 주요 사망원인이 암 및 심혈관계 질병이며, 계속 증가 추세에 있다. 이에 따라 심혈관계 질병에 도움이

*Corresponding author. E-mail : songuta@ghu.ac.kr Phone : 82-62-958-7595, Fax : 82-62-958-7591

Received 19 September 2018; Revised 19 October 2018; Accepted 3 December 2018.

Copyright (c) The Korean Society of Food Preservation. All rights reserved.
되는 것으로 알려진 $\omega-3$ 지방산을 다량 함유한 어패류의 소비 또한 증가하고 있다. 그러나 어패류들은 불포화지방 산의 다량함유로 유지의 산화 및 산패가 쉬워서 다양한 제품화 및 저장·유통에 대한 어려움이 있다. 냉장 유통시스 템의 성장으로 다양한 제품들이 빠르고 간편한 즉석편의식 의 형태로 개발-유통되고 있으며, 다양한 어패류들도 냉장 냉동 유통시스템을 통해 4계절 내내 식탁에 쉽게 오를 수 있게 되었다. 원기회복을 돕는 보양식품의 하나인 민물장 어(Anguilla japonica 또는 Anguilla bicolor)는 뱀장어로도 불리우며 불포화지방산이 풍부한 식품이다. 뱀장어 양식기 술의 발달과 냉장냉동 유통시스템의 발전으로 이전보다 장어의 소비가 증가하고 있다 $(2,3)$. 그러나 민물장어의 구 성성분 및 제품개발과 관련한 다양한 연구(3-6)에도 불구하 고 지질 산화 안정성에 관한 연구는 미흡하다. 이에 본 연구 
에서는 불포화지방산 함량이 높은 것으로 알려진 민물장어 의 지질 산화를 낮추는 데 도움을 줄 수 있는 전처리용 항산화 추출물을 탐색하고자 한다.

\section{재료 및 방법}

\section{재료 및 시료추출}

민물장어의 과산화 억제를 위한 전처리용 주정 추출물을 준비하기 위해 생강, 계피, 양파는 일반 대형마트에서 국산 제품으로 구입하였고, 헛개(Hovenia dulcis Thunb)나무는 장흥헛개영농조합에서 구입하였다. 양파는 $2 \mathrm{~cm}$ 두께로 썰어 식품 건조기(식품건조기 6단, Liquip, Hwaseong, $\mathrm{Korea})$ 에서 건조 $\left(35^{\circ} \mathrm{C}, 36\right.$ 시간 $)$ 하여 사용하여, 생강을 제외 한 3종의 시료는 건조한 상태로 사용하였다. 주정 추출물을 만들기 위해 4종의 각 시료 $200 \mathrm{~g}$ 에 과실주를 담는데 사용하 는 시판소주 $\left(30^{\circ}\right) 1 \mathrm{~L}$ 를 넣어 압력중탕기능을 가진 전기 약탕기(OC-2300R, OCOO Co., Ltd., Boryeong, Korea)를 이용하여 $112^{\circ} \mathrm{C}$ 에서 4 시간 추출한 후 거즈로 1 차 여과하고 여과지(Whatman No.1 filter paper, Whatman International Ltd., Darmstadt, Germany)로 2차 여과하여 합한 것을 최종 주정 추출물로 사용하였다. 추출물의 수율은 $68 \pm 4 \%$ 정도 였다. 추출용매로 소주를 선택한 것은 실제 장어 전처리 적용에 쉽게 활용할 수 있는 용매를 고려했다. 또한 여러 연구에서 순수 에탄올이나 물보다 희석된 에탄올 용매로 추출했을 때 항산화 효과가 높았던 보고가 있었다(7-9).

\section{장어 전처리 및 장어유 추출}

실험에 사용한 장어( $A$ bicolor pacifica)는 300-320 g 크기 였으며, 머리, 내장, 뼈를 제거한 후 1차 세척한 손질장어를 사용하였다. 꼬리 부분을 제거한 장어 $250 \mathrm{~g}$ 에 주정 추출물 $5 \mathrm{~g}$ (장어무게의 $2 \%$ 정도)을 장어 전체에 고루 바른 후 수분 활성이 90-91 정도가 될 때까지(Aw Meter, HP23-AW, Rotronic, Aargau, Switzerland) $35^{\circ} \mathrm{C}$ 에서 15 시간 정도 열풍 건조(식품건조기 6단, Liquip, Hwaseong, Korea)하여 실험 에 사용하였다. 반건조한 장어는 장어유를 추출할 때까지 진공포장하여 냉장보관한 후 사용하였다. 냉장보관 0 일, 7 일, 21 일에 장어유를 추출하여 산가 및 과산화물가를 측정 했고 이를 통해 항산화 효과를 확인하였다.

장어유의 추출은 Folch 등(10)의 방법에 준하여 추출하였 다. 잘게 자른 반건조 장어 $60 \mathrm{~g}$ 을 클로로포름:메탄올 $(2: 1$, $\mathrm{v} / \mathrm{v})$ 혼합액 $300 \mathrm{~mL}$ 에 넣고 균질화기(SMG-G, Shinsang, Co., Ltd., Seoul, Korea)로 추출한 후 여과하였다(Whatman No.1 filter paper, Whatman International Ltd.). 잔사에 다시 클로로포름-메탄올 혼합액을 $250 \mathrm{~mL}$ 가하여 균질화기로 추출하는 조작을 두 번 반복하였다. 얻은 여과액을 모두 합하여 분액깔대기에 옮겨 소량의 증류수를 넣어 혼합한
후 15-20시간 방치한 후 클로로포름 층을 분리하고, $\mathrm{Na}_{2} \mathrm{SO} 4$ 로 탈수시켜 여과하였다(Whatman No.1 filter paper, Whatman International Ltd.). 걸러진 여과액을 회전 진공 농축기(Rotavaor R-215, Büchi, Germany)로 $40^{\circ} \mathrm{C}$ 에서 감압 농축하여 장어유를 얻었다.

\section{$\mathrm{DPPH}$ 소거능 효과}

$\mathrm{DPPH}$ 소거능 효과의 측정을 위해 주정 추출물을 여과지 (Whatman No.1 filter paper, Whatman International Ltd.)에 한 번 거른 액상의 추출물을 사용하였다. DPPH 라디칼 소거 효과는 UV-분광광도계(UV-1650, Shimadzu, Kyoto, $\mathrm{Japan}$ )를 이용하여 흡광도 $517 \mathrm{~nm}$ 에서 측정하였다(11).

\section{산가 및 과산화물가 측정}

반건조 장어유 $1-2 \mathrm{~g}$ 을 취하여 식품공전의 방법을 이용하 여 산가 및 과산화물가를 측정하였다 $(12,13)$.

\section{리놀레산 및 장어유 과산화 억제 효과}

반건조 장어유 $0.2 \mathrm{~mL}$ (또는 linoleic acid $0.13 \mathrm{~mL}$ )에 $100 \%$ 에탄올 $10 \mathrm{~mL}$ 과 $50 \mathrm{mM}$ 인산완충액 $(\mathrm{pH} 7.4) 10 \mathrm{~mL}$ 을 넣고, 주정 추출물 $1 \mathrm{~mL}$ 을 $50 \mathrm{~mL}$ conical tube에 넣고 최종 용액양이 $25 \mathrm{~mL}$ 이 되도록 증류수를 첨가하여 $40^{\circ} \mathrm{C}$ 항온수 욕조(JSSB-30T, JSR, Gongju, Korea)에서 20일간 반응시켜 과산화를 유도하였다. 과산화물가의 측정은 thiocyanate method를 이용하여 흡광도 $500 \mathrm{~nm}$ 에서 측정하였다(14).

\section{통계처리}

각 실험군 간의 비교분석은 SPSS 21 통계프로그램(IBM, Seoul, Korea) 을 이용하여 ANOVA 다중분산 분석 후 $5 \%$ 유의수준에서 $(\mathrm{a}=0.05)$ Duncan's multiple range test를 이용 하여 유의성을 검증하였다.

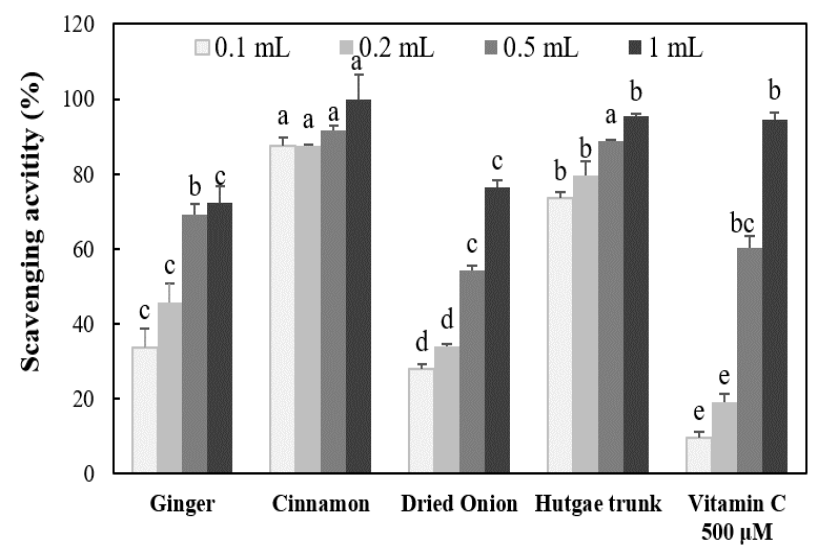

Fig. 1. DPPH radical scavenging effect of ethanol extracts from plants.

All values are mean $\pm \mathrm{SD}(\mathrm{n}=3)$. Values with different superscripts within the same concentration are significantly different $\mathrm{p}<0.05$. 


\section{결과 및 고찰}

\section{주정 추출물의 $\mathrm{DPPH}$ 소거활성}

소주 $\left(30^{\circ}\right)$ 로 추출한 4 종류의 주정 추출물들의 $\mathrm{DPPH}$ 소 거 활성은 농도의존적으로 활성이 증가하였다(Fig. 1). 활성 이 높았던 것은 계피 추출물과 헛개나무 추출물이었으며, 이들 추출물들의 활성은 대조구로 사용한 비타민 C 500 $\mu \mathrm{M}$ 의 활성보다 높았다 $(\mathrm{p}<0.05)$. 계피 및 헛개나무 추출물 들의 $0.1 \mathrm{~mL}$ 의 활성은 생강 및 건조양파 추출물 $0.5 \mathrm{~mL}$ 의 활성보다 높게 나타났으며, 비타민 C $500 \mu \mathrm{M} 0.5 \mathrm{~mL}$ 의 활성보다 높게 나타났다. $\mathrm{Kim}$ 등(9)의 5 종(겨자, 후추, 고추 냉이, 계피, 정향)의 향신료 에탄올 추출물의 항산화 효과 연구에서 계피는 항산화 활성이 높았으며, 특히 다른 추출 물에 비해 상대적으로 저농도에서 $\mathrm{DPPH}$ 활성이 높은 것으 로 보고된 바 있다. 본 연구의 결과처럼 계피 및 헛개나무 추출물의 $\mathrm{DPPH}$ 라디칼에 대한 높은 전자공여능 효과에 대한 연구도 보고된 바 있다 $(7,9,15,16)$.

\section{반건조 장어의 산가}

유지의 품질관리에서 중요지표로 사용되는 산가는 유리 지방산의 함량을 측정하는 데 사용된다. 산가가 높을수록 유지가 변질되고 산패한 것으로 판단한다(1). 주정 추출물 을 처리하지 않은 반건조 장어(대조구)의 산가는 $6.6 \mathrm{mg}$ $\mathrm{KOH} / \mathrm{g}$ 이었다. 주정 추출물을 처리한 반건조 장어의 산가 는 4.4-6.6 mg KOH/g로 나타났다(Table 1). 무처리 반건조 장어에 비해 상대적으로 산가가 낮았던 반건조 장어는 생강 과 계피 추출물로 전처리하여 건조한 경우 $(4.4 \mathrm{mg} \mathrm{KOH} / \mathrm{g})$ 였다 $(\mathrm{p}<0.05)$. 이들 추출물들은 장어의 건조 동안 $\left(35^{\circ} \mathrm{C}, 15\right.$ 시간) 유리지방산의 증가를 억제한 것으로 나타났다. 시판 중인 반염건조 붕장어의 산가는 평균 $8.5 \mathrm{mg} \mathrm{KOH} / \mathrm{g}$ 으로 보고된 바 있다(17). 건조양파와 헛개나무 추출물은 장어의 건조 동안 유리지방산의 생성을 억제하는 데 효과가 낮은 것으로 나타났다. $\mathrm{Kim}$ 등(12)의 연구에서 불포화지방산 함 량이 높은 갈색거저리 유충의 건조 전처리 방법에 따라

Table 1. Acid value of semi-dried eel treated with various plant extracts

\begin{tabular}{|c|c|c|c|}
\hline \multirow{2}{*}{ Extract } & \multicolumn{3}{|c|}{ Storage period (day) } \\
\hline & 0 & 7 & 21 \\
\hline Ginger & $4.38 \pm 1.08^{1 \mathrm{a} 2)}$ & $5.00 \pm 1.81^{\mathrm{a}}$ & $5.97 \pm 0.24^{\mathrm{a}}$ \\
\hline Cinnamon & $4.42 \pm 1.06^{\mathrm{a}}$ & $4.41 \pm 1.01^{\mathrm{a}}$ & $8.27 \pm 3.74^{a b}$ \\
\hline Dried onion & $5.99 \pm 1.84^{\mathrm{ab}}$ & $7.09 \pm 1.04^{b}$ & $7.40 \pm 0.81^{\mathrm{ab}}$ \\
\hline Hutgae trunk & $6.61 \pm 0.03^{\mathrm{b}}$ & $9.22 \pm 0.46^{c}$ & $8.85 \pm 1.95^{\mathrm{ab}}$ \\
\hline Control & $6.61 \pm 0.04^{b}$ & $8.36 \pm 0.06^{\mathrm{bc}}$ & $9.63 \pm 0.18^{b}$ \\
\hline
\end{tabular}

저장 0 일의 산가가 다르게 나타났는데, 건조 등 시료의 전처 리 방법이 산가에 영향을 미치는 것으로 제안하였다. 냉장 보관 7일에 대조구의 산가는 $8.4 \mathrm{mg} \mathrm{KOH} / \mathrm{g}$ 으로 냉장보관 전보다 $26.5 \%$ 산가가 증가하였다. 생강과 계피 추출물로 전처리한 장어의 냉장보관 7일의 산가는 유의적으로 낮았 다 $(\mathrm{p}<0.05)$. 냉장 보관 21일 동안 산가가 낮아 항산화 효과 가 높게 평가된 것은 생강추출물을 처리한 경우였다. 냉장 보관 21 일에 대조구의 산가가 $9.6 \mathrm{mg} \mathrm{KOH} / \mathrm{g}$ 이었으며, 생강 추출물을 처리한 장어의 산가는 $6.0 \mathrm{mg} \mathrm{KOH} / \mathrm{g}$ 으로, 대조구 에 비해 $60 \%$ 정도 장어의 유리지방산 생성을 억제한 것으 로 판단되었다. 저장 중 양식뱀장어 튀김의 산화안정성 및 지방산 조성의 변화 연구에서는 대조구보다 각종 처리구의 산가가 낮은 이유를 시료에 처리한 물질들에 의해 자유라디 칼의 활성을 저하시켜 지질의 산화를 억제하는 것으로 제안 하였다(18). 생강 추출물 $(80 \%$ 에탄올)이 6종(마늘, 양파, 파, 부추, 무, 생강)의 황함유 채소 에탄올 추출물 중에서 총 폴리페놀 함량이 가장 높았으며, 높은 전자 공여능 등의 항산화 활성을 갖는 연구보고가 있다(19). 또한 생강즙이 고등어의 냉동저장 6 주 동안 상대적으로 산가를 낮추어 유리지방산의 생성을 억제하는 데 효과적이라는 연구가 보고된 바 있다(20). 본 연구에서도 생강추출물이 라디칼 소거활성에 대한 효과는 높지 않았지만 산가는 낮추어 장어 의 유리지방산 생성 억제에는 효과가 있는 것으로 판단되었 다.

\section{반건조 장어의 과산화물가}

항산화 추출물로 전처리하여 반건조한 장어의 과산화물 가는 13.3-16.1 meq/kg으로 나타났고, 대조구인 무처리한 장어 $(18.6 \mathrm{meq} / \mathrm{kg})$ 보다 대체로 낮게 나타났다(Table 2). 추 출물의 전처리가 장어의 건조 동안 과산화를 낮추는 것으로 판단되었다. 건조 후 냉장보관 전의 과산화물가가 낮았던 것은 생강과 계피 추출물을 처리한 경우였다 $(\mathrm{p}<0.05)$. 냉장 보관 7일 및 21 일의 과산화물가는 무처리한 장어의 경우 크게 상승하여 $19.6 \mathrm{meq} / \mathrm{kg}$ 과 $30.3 \mathrm{meq} / \mathrm{kg}$ 으로 나타났고,

Table 2. Peroxide value of semi-dried eel treated with various plant extracts

\begin{tabular}{cccc}
\hline \multirow{2}{*}{ Extract } & \multicolumn{3}{c}{ Storage period (day) } \\
\cline { 2 - 4 } & 0 & 7 & 21 \\
\hline Ginger & $13.25 \pm 2.21^{1) 22}$ & $15.10 \pm 1.74^{\mathrm{a}}$ & $19.70 \pm 1.27^{\mathrm{ab}}$ \\
Cinnamon & $13.98 \pm 4.47^{\mathrm{a}}$ & $16.48 \pm 0.10^{\mathrm{a}}$ & $24.09 \pm 2.23^{\mathrm{c}}$ \\
Dried onion & $15.10 \pm 0.97^{\mathrm{b}}$ & $21.21 \pm 1.43^{\mathrm{c}}$ & $22.24 \pm 2.66^{\mathrm{bc}}$ \\
Hutgae trunk & $16.07 \pm 1.36^{\mathrm{c}}$ & $17.21 \pm 0.38^{\mathrm{ab}}$ & $17.28 \pm 0.70^{\mathrm{a}}$ \\
Control & $18.63 \pm 1.10^{\mathrm{d}}$ & $19.59 \pm 1.90^{\mathrm{bc}}$ & $30.30 \pm 5.29^{\mathrm{d}}$ \\
\hline
\end{tabular}

${ }^{1)}$ All values are mean $\pm \mathrm{SD}(\mathrm{n}=3)$.

${ }^{2)}$ Values with different superscripts within the same concentration are significantly different $\mathrm{p}<0.05$. 
냉장보관 21 일 동안 과산화물가는 $62.6 \%$ 증가했다. 보관 7 일에서 과산화 억제효과가 높게 나타난 것은 생강, 계피, 헛개나무 추출물이었다. 냉장보관 21 일에 과산화물가가 낮 았던 것은 헛개나무 추출물을 처리한 경우로 냉장보관 초기 의 과산화물가는 다른 추출물을 처리한 경우보다 약간 높았 지만, 21 일 동안의 과산화물 생성은 $7.5 \%$ 증가한 정도로낮 아 과산화를 억제하는 효과가 높은 것으로 판단되었다. 장 어의 반건조 후 과산화물가가 낮았던, 생강과 계피 추출물 을 처리한 경우 냉장보관 21 일에는 과산화물이 각각 $48.7 \%$ 와 $72.3 \%$ 증가하여 냉장보관이 길어질수록 지질 과산화 억제에 대한 항산화 효과는 낮은 것으로 판단되었다. 유리 지방산 생성 억제효과와 유사하게 생강, 계피 추출물은 장 어의 건조동안 초기 과산화물 생성을 억제하고, 헛개나무 추출물은 21 일간 냉장보관 동안 반건조 장어의 과산화를 억제하는 것으로 나타났다.

\section{리놀레산 과산화 억제효과}

리놀레산 또는 장어유에 추출물을 첨가하여 $40^{\circ} \mathrm{C}$ 에서 일정기간 산화반응을 유도하여 추출물의 지질과산화에 대 한 억제효과를 측정하였다(Fig. 2). 과산화물(hydroperoxide) 은 불안정하여 자동산화의 진행에 따라 최고치에 도달한 후 쉽게 2 차 산화생성물들로 분해되어 감소하게 되므로(1), 과산화물 생성의 정도를 통해 지질산화의 초기단계의 산패 도 또는 산화 속도를 비교할 수 있다(20). 추출물을 넣지 않은 대조구는 반응 12 일까지 서서히 과산화물이 증가하다 반응 12 일에 크게 증가하였고, 반응 20 일에는 추출물을 넣 은 것보다 상대적으로 높은 흡광도를 보여 과산화물이 많이 생성 된 것으로 판단되었다. 리놀레산의 과산화 억제에 효 과가 있었던 것은 생강과 헛개나무 추출물이었다. 이 두 추출물을 넣은 경우는 반응 20 일 동안 과산화물이 크게 증가하지 않아 리놀레산의 과산화를 억제한 것으로 판단되

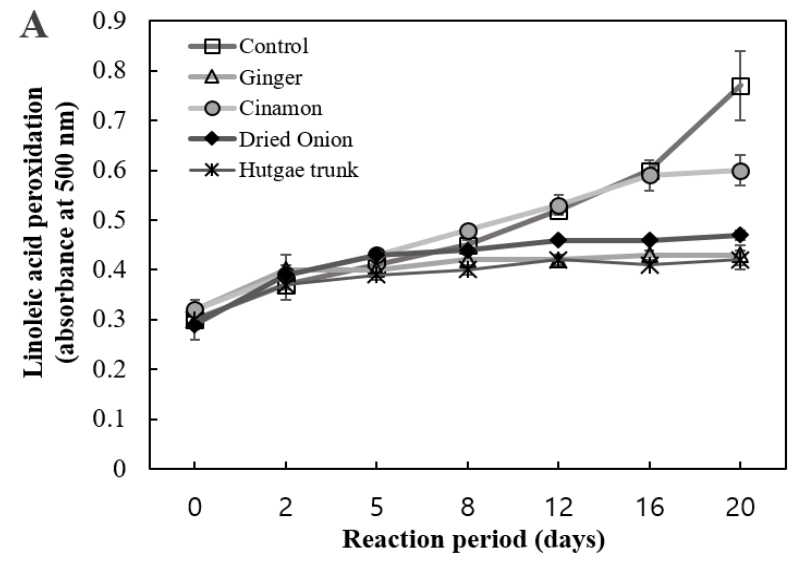

었다. 계피 및 건조양파 추출물은 대조구에 비해 흡광도가 낮아 약간의 과산화 억제효과가 있으나 생강과 헛개나무 추출물보다는 리놀레산의 과산화 억제에는 상대적으로 효 과가 낮은 것으로 판단되었다.

\section{반건조 장어유 과산화 억제효과}

리놀레산을 대신하여 반건조 장어유에 각 주정 추출물을 넣고 일정기간 산화반응을 유도하여 장어유에 대한 추출물 의 과산화 억제 효과를 측정하였다(Fig. 2). 대조구의 경우 리놀레산 산화와 유사하게 반응 8 일까지는 과산화물의 증 가가 크지 않았으나 반응 12 일부터 과산화물 생성이 크게 증가하였고 반응 20 일에는 생성된 과산화물이 분해하기 시작하는 것으로 판단되었다. 반응 20 일 동안 안정적으로 장어유의 과산화를 억제한 것은 생강 및 건조양파 추출물을 넣은 경우였다. 계피 추출물은 다른 추출물에 비해 장어유 의 초기 과산화 억제에는 상대적으로 효과가 낮으나 반응 20 일 동안 헛개나무추출물이나 대조군에 비해 과산화물의 생성이 크게 증가하지 않아 어느정도 과산화를 억제하는 효과가 있는 것으로 판단되었다. 헛개나무 추출물은 반응 12 일까지는 과산화를 억제하여 대조구에 비해 과산화 유도 기간을 지연시키는 것으로 나타났으나 반응 16 일에 과산화 물의 생성이 크게 증가하여, 장기간 반건조 장어유의 과산 화를 억제하지는 못하는 것으로 판단되었다. 헛개나무 추 출물을 처리한 반건조 장어의 경우 냉장보관 21 일 동안 과산화물가의 상승이 낮았던 것은 헛개나무 추출물이 장어 의 과산화 유도기간을 지연시켜 과산화를 억제한 효과라고 판단되었다. 리놀레산의 과산화 억제에는 효과가 낮았던 계피 추출물이 반건조 장어유의 과산화 억제에는 상대적으 로 효과가 높게 나타났다. Kim 등(21)의 연구에서 계피 물추 출물은 총페놀성 함량은 높았으나 $110^{\circ} \mathrm{C}$ 대두유의 과산화 유도기간을 지연시키는 데는 비교했던 다른 추출물에 비해

Fig. 2. Antioxidant effects of ethanol extracts from plants on peroxide reaction of linoleic acid and eel oil.

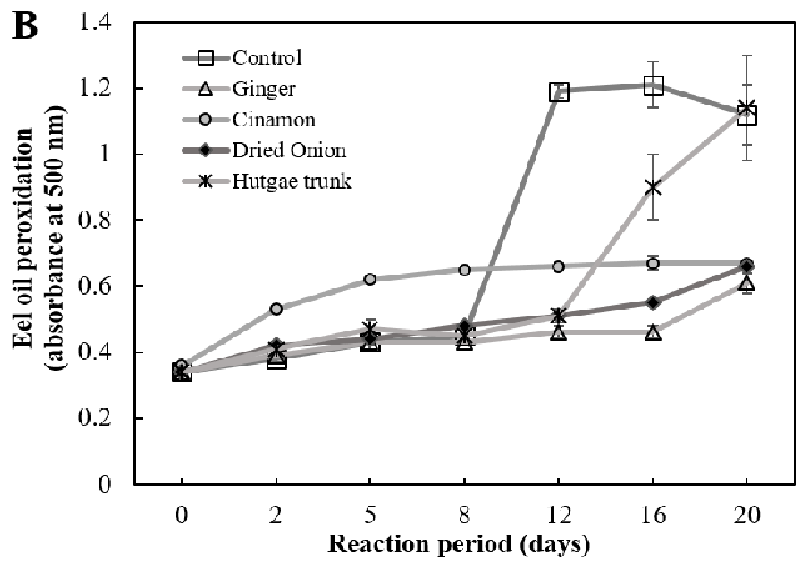


상대적으로 효과가 낮은 것으로 보고된 바 있다. 또한 계피 에탄올 추출물의 과산화 억제효과는 농도의존적으로 상승 하였으나 과산화 억제효과가 크지 않았다는 보고가 있다 (9). 본 연구에서 상대적으로 높은 DPPH 라디칼 소거활성 에 비해, 산가나 과산화물가의 효과가 크지 않았던 계피 추출물은 반건조 장어유에서 과산화 유도기간의 지연을 통해 과산화 억제에 도움을 주는 것으로 판단되었다.

생강 추출물은 DPPH 소거 활성은 상대적으로 높지 않았 으나 장어의 유리지방산 생성 및 과산화 유도기간 지연, 과산화물 생성 억제에 효과가 있는 것으로 나타났다. 생강 즙 및 생강 에탄올 추출물이 정어리유, 고등어, 꽁치육의 과산화 억제에 효과가 있는 것으로 보고된 바 있다 $(20,22,23)$. 본 연구의 결과를 종합해 볼 때, 장어의 건조 전 전처리에 생강, 계피 주정 추출물을 적용하는 것은 장어 의 건조 및 냉장보관 중의 과산화를 억제하며, 건조양파 및 헛개나무 추출물을 장어 전처리에 사용하는 것은 반건조 장어의 과산화 유도기간을 지연시키고 과산화물 생성을 어느 정도 억제하는 효과가 있는 것으로 판단되었다.

\section{요 약}

장어의 과산화 억제를 위해 생강, 계피, 건조양파, 헛개나 무를 시판 소주 $\left(30^{\circ}\right)$ 를 용매로 하여 추출한 것을 장어 전처 리용 주정 추출물로 사용하였다. 장어무게의 $2 \%$ 양의 주정 추출물을 장어 전체에 고루 바른 후 $35^{\circ} \mathrm{C} 15$ 시간 열풍건조 한 후 실험에 사용하였다. 주정 추출물의 항산화 활성은 $\mathrm{DPPH}$ 소거 활성, 반건조 장어의 산가, 과산화물가, 리놀레 산 및 반건조 장어유 과산화 지연반응을 통해 확인하였다. $\mathrm{DPPH}$ 소거 활성이 가장 높았던 것은 계피 추출물이었으며, 다음으로 활성이 높았던 것은 헛개나무, 건조양파, 생강 추출물이었다(p<0.05). 21 일 동안 냉장보관한 장어의 산가 측정에서 생강추출물로 처리한 경우 산가가 가장 낮았다. 유리지방산 생성 억제효과와 유사하게 생강 추출물이 장어 의 열풍건조 동안 초기 과산화물 생성을 억제하고, 냉장보 관 21일 동안 반건조 장어의 과산화물의 생성을 억제하는 것으로 나타났다. 과산화 유도반응 20 일 동안 리놀레산의 과산화를 억제하는 효과가 높게 나타난 것은 헛개나무, 생 강, 건조양파 추출물이었다. 과산화 유도반응 20 일 동안 반건조 장어유의 과산화를 지연시킨 효과가 높았던 것은 생강, 계피, 건조양파 추출물이었으며, 헛개나무 추출물의 경우 반건조 장어유의 과산화 유도기간을 지연시키는 효과 가 있는 것으로 판단되었다. 본 연구의 결과를 종합해 볼 때, 장어의 건조 전 전처리에 생강과 계피 주정 $\left(30^{\circ}\right.$ 소주)추 출물을 적용하는 것은 장어의 건조 및 반건조 장어의 냉장 보관 중의 과산화를 억제하며, 건조양파 및 헛개나무 추출 물의 장어 전처리 사용은 반건조 장어의 과산화 유도기간을
지연시키고 과산화물 생성을 어느 정도 억제하는 효과가 있는 것으로 판단되었다.

\section{감사의 글}

본 연구는 중소벤처기업부와 한국산업기술진흥원의 “지 역특화산업육성사업(R\&D, R0006328)"으로 수행된 연구 결과입니다.

\section{References}

1. Cho SH, Cho KR, Kang MS, Song MR, Joo NY (2011) Food science. Kyomunsa, Paju, Korea, p 101-106

2. Statistics Korea. http://www.kostat.go.kr/portal/korea/kor _nw/3/ (accessed July 2018)

3. Ahn JC, Chong WS, Na JH, Yun HB, Shin KJ, Lee KW, Park JT (2015) An evaluation of major nutrients of four farmed freshwater eel species (Anguilla japonica, $A$ rostrata, $A$ bicolor pacifica and $A$ marmorta). Kor J Fish Aquat Sci, 48, 44-50

4. Kim HY, Shin JW, Sim GC, Park HO, Kim HS, Kim SM, Cho JS, Jang YM (2000) Comparison of the taste compounds of wild and cultured eel, puffer and snake head. Korean J Food Sci Technol, 32, 1058-1067

5. Choi BD, Kang SJ, Ha YL, Kim SY, Lee JJ (2006) Oxidative stability of lipids from eel (Anguilla japonica) fed conjugated linoleic acid. J Korean Soc Food Sci Nutr, 35, 61-67

6. Moon WS, Yoo SS (2016) Study on the optimization of eel dipping sauce added with Bokbunja (Rub corearus Miquel) vinegar. Culinary Science Hos Res, 22, 66-77

7. Kim NM, Sung HS, Kim WJ (1993) Effect of solvents and some extraction conditions on antioxidant activity in cinnamon extracts. Korean J Food Sci Technol, 25, 204-209

8. Shon MY, Seo JK, Kim HJ, Sung NJ (2001) Chemical compositions and physiological activities of Doraji (Platycodon grandiflorum). J Korean Soc Food Sci Nutr, 30, 717-720

9. Kim J, Kim SA, Yun WK, Kim EJ, Woo MK, Lee MS (2004) Antioxidative effect of ethanol extract for 5 kinds of spice. J Korean Soc Food Sci Nutr, 33, 1426-1431

10. Folch J, Lees M, Stanley GHS (1957) A simple method for the isolation and purification of total lipids from animal tissues. J Biol Chem, 226, 497-509 
11. Song HS, Kim DP, Jung YH, Lee MK (2007) Antioxidant activities of red Hamcho (Salicornia herbacea L.) against lipid peroxidation and the formation of radicals. Korean J Food Nutr, 20, 150-157

12. Kim SY, Son YJ, Kim SH, Kim AN, Lee GY, Hwang IK (2015) Studies on oxidative stability of Tenebrio molitor larvae during cold storage. Korean J Food Cook Sci, 31, 62-71

13. Ministry of Food and Drug Safety http://www.foodsafety korea.go.kr/foodcode (accessed July 2018)

14. Song HS, Ukeda H, Sawamura M (2001) Antioxidative activity of citrus peel essential oils and their components against linoleic acid oxidation. Food Sci Technol Res, 7, 50-56

15. Jung SY, Lim JS, Song HS (2012) Alcohol dehydrogenase activity and sensory evaluation of Hutgae (Hovenia dulcis Thunb) fruit soy sauce. Korean J Food Nutr, 25, 747-754

16. Won SB, Song HS (2013) Antioxidant activity and sensory evaluation in soy sauce with fruit, stem, or twig of Hovenia dulcis Thunb. Korean J Food Nutr, 26, 258-265

17. Choi JD, Kang SI, Kim YJ, Lee SG, Heu MS, Kim JS (2015) Sanitary quality characterization of commercial semi-dried conger eel Conger myriaster and the guideline for controlling quality. Korean J Fish Aquat Sci, 48, 417-425

18. Hong SP, Kim SY, Jeong EJ, Shin DH (2005) The change in fatty acid and oxidative stability of frying cultured eel bone during the storage. J Fd Hyg Safety, 20, 89-97

19. Kim KH, Kim HJ, Byun MW, Yook HS (2012) Antioxidant and antimicrobial activities of ethanol extract from six vegetables containing different sulfur compounds. J Korean Soc Food Sci Nutr, 41, 577-583

20. Lee YK, Lee HS (1990) Effects of onion and ginger on the lipid peroxidation and fatty acid composition of mackerel during frozen storage. J Korean Soc Food Nutr, 19, 321-329

21. Kim MH, Kim MC, Park JS, Kim JW, Lee JO (2001) The antioxidative effects of the water-soluble extracts of plants used as tea materials. Korean J Food Sci Technol, 33, 12-18

22. Byun HS, Kim SB, Park YH (1986) Antioxidative effect of ginger extracts on fish oil. Bull Korean Fish Soc, 19, 327-332

23. Cook CY (1995) Antioxidative effect of ethanol extract of ginger on mackerel pike (Cololabis saira) flesh. J Korean oil Chemists Soc, 12, 43-46 